\title{
Policy Implementation To Arrange The Street Vendors By The Government of Denpasar City, Bali Province
}

\author{
Anak Agung Gede Oka Wisnumurti, Ni Nyoman Reni Suasih
}

\author{
A.A Gede Oka Wisnumurti Faculty of Social and Political Sciences, Warmadewa University \\ Ni Nyoman Reni Suasih, Faculty of Economics, Warmadewa University
}

\begin{abstract}
Street vendors are informal types of work (small businesses) that arise primarily in urban areas, carried out by low-income people (daily salaries), have limited capital, and consist of only one worker (self employed). The presence of street vendors in various major cities in Indonesia, including in Denpasar City, has become a dilemma that creates pro-contra, and has the potential to clash between citizens and officials of government. This is because street vendors sell their wares in public places that are considered strategic, thus disrupting public order, and other public peace. On the other hand, according to one of the SDG's programs, the government has an obligation to realize decent work for everyone. In the effort of structuring street vendors, as well as helping small traders of economic actors in the informal sector, the government of Denpasar City issues Denpasar City Local Law No. 2 of the year 2015 about Street Vendors. Therefore, an analysis is needed to find out the implementation of Denpasar City Local Law No. 2 of the year 2015, as well as to find out the supporting factors and inhibiting factors of its implementation. This research is a qualitative descriptive study, where the data obtained through the process of observation, interviews, and documentation studies. Selection of informants through purposive sampling technique, and data analysis techniques using Merilee S. Grindle's theory of policy implementation and contingency theory by James Lester. The results of the analysis show that the implementation of Denpasar City Local Law No. 2 of the year 2015 for arranging street vendors is still faced with several obstacles such as: lack of location according to allotment, lack of adequate budget, evaluation that is rarely done, and sanctions that are not in accordance with what is written in the Regional Regulation and the lack of understanding of street vendors on the local law. An interesting finding is that it turns out that governemtn of villages and custom village have an important role in organizing street vendors in their areas.
\end{abstract}

Keywords: Denpasar City Local Law No. 2 of the Year 2015, implementation of policy, street vendor

\section{Introduction}

Concentration of the implementation of development that tends to be centered in urban areas results in a rampant flow of population from rural to urban areas (urbanization) to obtain a better welfare in the hope of getting a job after moving to the city. But in addition to being not equipped with skills, the constraints of obtaining employment in the formal sector in urban areas also encourage job seekers to work in the informal sector which includes; small scale businesses, small industry businesses, street vendors, hawkers, scavengers and others (Madjid, 2013: 60).

In general, the informal sector is a work-intensive type of work, in the sense that there is no need for high education, special skills, and large capital. But as a choice of employment, the informal sector has several weaknesses such as lack of certainty of results and sustainability obtained, and relatively small income. The informal sector creates employment opportunities 
in two ways, namely directly and indirectly. Directly the informal sector is able to absorb workers who can directly enter the workforce. Indirectly, the informal sector is able to expand the market created through distribution and procurement of raw materials and trading activities on the other side (Kurniadi and Tangkilisan, 2002: 21).

One form of work in the informal sector that appears in urban areas is street vendors (hereinafter referred to as street vendors). The definition of street vendor has many meanings, including small traders who in their activities utilize locations that are not intended as a place to sell, such as road bodies, sidewalks, and store yards. Street vendor is also understood as a trader who puts his wares on the roadside with a width of five feet (5feet) from the sidewalk or the edge of the road (Madjid, 2013: 63). Street vendor as the informal sector has characteristics including: easy to enter, flexible in time and place, and dependent on local resources with a relatively small business scale (Sastrawan, 2015).

Street vendor activities in strategic locations and crowded visitors. The existence of street vendors who work in the area often raises various problems, one of the most prominent is the problem of cleanliness and the environment. Waste from used food or beverage waste sold by street vendor is not disposed of in its place, thus disrupting the beauty of the place. As with the problems that occur in big cities, this happens also in Denpasar City. The city of Denpasar was chosen by job seekers because they had adequate infrastructure to support a job.

The increasing presence of street vendors in Denpasar, making local regulations violated also increased, based on data obtained from Denpasar City Satpol PP, the number of violations each day reached 15 reports of violations from Denpasar's Online People's Service (PRO), private messages, or telephone complaints from the public, also the results of patrolling using shifts every day.

Street vendor is the party most affected by the enforcement of Regional Regulations by Satpol PP. PKL must obey the Regional Regulation as a form of contribution in realizing cleanliness and order in Denpasar City. But on the contrary, if the PKL does not obey the Regional Regulation, one of the decisive actions that must be taken by the Denpasar City Government is to control it as a manifestation of the enforcement of the Regional Regulation carried out by the Satpol PP. Local law enforcement in the form of reprimand, confiscation of merchandise, until the determination of sanctions in the form of minor criminal acts (hereinafter referred to as tipiring) by Satpol PP often results in street vendors suffering material and non-material losses.

Responding to the phenomenon of repeated curbing by the Satpol PP to street vendor, and with the Government's awareness of the contribution of PKL in moving the economic sector, Denpasar City Government (hereinafter referred to as Denpasar City Government) then issued Denpasar City Local Law No. 2 of the Year 2015 concerning Street Vendors (hereinafter called Local Law No. 2 of the Year 2015) as a change from Denpasar City Local Law No. 3 of the Year 2000 concerning Hygiene and Public Order (hereinafter referred to as Local Law No. 3 of the Year 2000). This was based on the initiative of the Denpasar City Government to conduct environmental arrangements in the City of Denpasar and at the same time help small traders of economic actors in the informal sector.

The regulation contains zoning where street vendors are prohibited from selling (sidewalks, riverbanks, green lines, city parks and public places), efforts to organize and empower street vendors so that their existence can make a real contribution in supporting the economy and remain supported by clean, healthy urban environment, beautiful and improve the economy of the community in accordance with the icon of Denpasar City which has a cultural perspective in accordance with the philosophy of Tri Hita Karana. When released, the regulation was socialized by the municipal government in collaboration with Satpol PP to stakeholders including the heads of services, village heads, and village heads. Then the City 
Government also installed signposts and banners prohibited from selling according to the contents of the Regional Regulation in strategic locations prone to street vendors.

In addition, for structuring, Denpasar City Government is assisted by related parties such as villages or traditional banjar in Denpasar City, and also Market. The government hopes that good synergy between street vendors, villages or custom groups and Denpasar City Satpol PP can be realized. Other goals to be achieved are decreasing the number of violations of selling locations, creating a clean, comfortable, beautiful and healthy environment in Denpasar City, as well as improving the economy of the community in accordance with the vision and mission of the City of Denpasar which is inseparable from the iconic city with cultural insight.

This study will discuss how to implement Local Law No. 2 of the Year 2015in Street Vendor Arrangement in Denpasar City. Then to find out what factors influence the implementation of Regional Regulation No. 2 of 2015 in organizing street vendors in Denpasar City. Where the regulation has been considered not to work effectively. Ineffectiveness it can be seen from the large number of street vendors still netted policing in public places that are not used as a location to sell and receive the sanction of a reprimand, forfeiture of merchandise, up to the threat of criminal sanctions to a maximum of 3 months imprisonment or a fine of $\mathrm{Rp}$ 1,000,000 00 (Number 50 of Local Law No. 2 of the Year 2015).

The informal sector in the context of economic development, is a by-product of the development of the formal sector that has characteristics that are contrary to the formal sector. The properties of the informal sector that reflects opposition to the formal sector, among others: a) On the marketing side, the transaction bargaining outside the formal legal system with the social activities of cultural prominence, $b$ ) the social behavior of the actors closely linked to the village and region of origin, c ) is an illegal activity that is always threatened with demolition, d) income economic actors of this sector valid but it is hidden and is referred to as the black economy or undergroundeconomy, e) Generally regarded perform the role of peripherals in the urban economy and diverse activities, $\mathrm{f}$ ) in running the business happen fierce competition among economic actors, g) Most self-employed, disorganized, small profits, h) Economic activities in the informal sector grow from the poor are done by the poor, and some consumers are poor people.

The purpose of this study is to find out the form of the implementation of Local Law No. 2 of the Year 2015 in Denpasar City which includes the structuring process carried out by the City Government and Satpol PP of Denpasar City as law enforcement agencies. To find out the factors that influence the implementation of street vendor arrangement in Denpasar City, both in the form of supporting factors and obstacles to the implementation process both from the government side and actors in the informal sector.

\section{Discussion}

\subsection{Implementation of Denpasar City Local Law No. 2 of the Year 2015}

Public policy comes from the words policy and public. According to Islamy (2009: 20) public policy (public policy) is, "A series of actions that are established and implemented or not implemented by a government that has a purpose or is oriented towards a specific goal for the benefit of the whole community". Policy making is an action that is established and implemented by the government and oriented towards achieving the objectives for the benefit of the community. A policy process, according to Wahad (2001: 29) there are at least four groups or types of actors involved, namely: a) rationalist groups; b) technician class; c) incremental groups; d) reformists. 
Policy implementation in principle is a way for a policy to achieve its objectives. To implement public policy, there are two choices of steps available, namely directly implementing in the form of a program or through a derivative policy formulation or derivative of the public policy. Policy implementation series can be observed clearly, starting from the program, to the project and to activities. The model adapts the mechanisms that are common in management, especially public sector management. The policy was derived in the form of programs which were later reduced to projects, and ultimately manifested in activities, both carried out by the government, the community and government cooperation with the community.

There are several theories from experts regarding the implementation of public policy. In analyzing the implementation of Perda Number 2 of 2015 in the arrangement of street vendors in Denpasar, there are two theories used, including policy implementation theory and contingency theory. In determining the level of performance of a policy implementation, the assessment of performance (performance measurement) is important. Performance appraisal is the application of methods used by researchers to answer the main questions in the implementation study, namely: (1) what is the content and purpose of a policy: (2) what steps must be taken to achieve these objectives: and (3) whether after these stages are carried out, the implemented implementation is able to realize the policy objectives.

The contents of the local law which regulate the arrangement of street vendors are in Chapter III Article 7 and 8 which explains that (1) the arrangement is carried out on the street vendors and the location of the street vendors' activities, structuring the location of the activities as referred to in paragraph (1) carried out in urban areas in accordance with the provisions of the Regional Regulation regulating spatial planning, and the Mayor arranges street vendors by: a) street vendor data collection, b) street vendor registration, c) street vendor location determination, d) street vendor removal and street vendor location removal, e) street vendor location rejuvenation.

Implementation of Local Law No. 2 of the Year 2015 which regulates street vendor arrangement in Denpasar City has not been running optimally. This can be seen from the observation that there are still many street vendors netted by control and the number of street vendors in Denpasar City continues to increase every year due to the attractiveness of Denpasar City as the Provincial Capital for the informal sector, lack of location according to allocation, lack of adequate budget, rare evaluation carried out, and sanctions that are not in accordance with what is written in the Perda, as well as the lack of understanding of PKL on the existence of the Perda are considered to be a factor that has not maximized the performance of this Regional Regulation. In fact, villages and adat groups play an important role in managing street vendors in their working areas, on the one hand the City Government and Satpol PP are not willing to interfere with customary rules to avoid disharmony in the community.

For researchers, law enforcement has not been effective enough. This is because there are still many street vendors selling at locations that are not intended and affected by the enforcement of the local regulation. Through observations at the Denpasar City Satpol PP office, researchers found at least three to four street vendors every day who were intercepted and their merchandise was secured by officers. The confiscated merchandise also varies, ranging from food, balloons, to snacks.

From several aspects of implementation theory, researchers use several aspects including: aspects of the desired degree of change, aspects of the location of decision making, aspects of program implementers, aspects of resources involved, and level of compliance and responsiveness. Where the desired degree of change from Regional Regulation No. 2 of 2015 is to organize street vendors in Denpasar City so that its existence can provide a real contribution in supporting the economy. The location of decision-making is entirely in the city 
of Denpasar as the maker of the regulation. The division of tasks is then submitted to the relevant Regional Organization (OPD). In Local Law No. 2 of the Year 2015, Civil Servant Investigators (PPNS) and Regional Device Organizations (OPD) who are entitled to enforce the Regional Regulation are the Denpasar City Satpol PP.

The level of compliance and responsiveness of local law enforcement in this case the Satpol PP of Denpasar City, and Tramtibum in each sub-district have gone well. This is because, both the Denpasar City Satpol PP to the members who are under Kasi Tramtibum regularly monitor the possibility of violating local regulations in the community. They go down to the field patrol every day whether there are complaints that enter or not and will act quickly if there are complaints from the public.

The City Government and Satpol PP of Denpasar City are not independent, there is Community Protection in each Village and the Public Order and Order Section (Tramtibum) in each District. In this study, the commitment of the City Government is included in the high category with sufficient capacity. low and the output produced is struggler or hard work. This is evidenced by the commitment of policy makers towards the results of high policies (Perda) and implementorun in carrying out their duties in accordance with their commitments (tupoksi). However, the capacity or supporting factors of the implementation of the Regional Regulation have not been fulfilled (budget, location, and data collection).

\subsection{Supporting and Inhibiting Factors of the Implementation of Denpasar City Local Law No. 2 of the Year 2015}

The concept of structuring and empowerment is an alternative solution to the development problems faced. The arrangement of the community requires an ongoing commitment from the government to improve the quality of Human Resources (HR) in order to always cultivate orderly and clean lives. Community empowerment is a concept of economic development that summarizes social values. This concept reflects the new paradigm of development, namely those that are "people-centered, participatory, emporing, and sustainable" (Kartasasmita, 1996). Empowerment has a two-way goal, first, to release the shackles of poverty, and secondly to strengthen the position of the society in the economic structure and power.

To realize community structuring, the main policy that can be pursued by the government is as follows: First, develop institutions through the establishment of a sound management organization with clear details of duties, authorities and responsibilities. Second, improving the ability of apparatus who can support community structuring activities to preserve the environment. Third, to promote spatial planning in the business world such as street vendors. Fourth, to strengthen the arrangement as a reference for regional development and strategic areas. Fifth, to strengthen control of spatial utilization, including safeguarding areas that have important assets for local governments. Sixth, improving the information system, monitoring and evaluation in community management.

Conceptually, community empowerment is an effort to increase the dignity of the layers of society who are now unable to escape the poverty trap and underdevelopment. In other words empowering is enabling and self-sufficient in society. Empowerment intended in this study is the empowerment of the informal sector, especially PKL groups as part of the community that needs their own management or management related to the resources they have.

There are several supporting factors in the implementation of the regulation of street vendors (in Denpasar City, namely: the suitability of the amount between the quantity and quality of human resources in this study. In terms of quantity, it is sufficient because its 
members are from the relevant DPOs, and the number of implementers in terms of enforcement of the Perda conducted by the City Satpol PP and in Kasi Tramtibum, each Subdistrict is deemed qualified. This is evident from the responsiveness of members of the Satpol PP to follow up on incoming complaints. The media used in the delivery of information and complaints, based on the results of the study can be seen that the media used are still semiconventional, namely in the form of complaints online, by telephone and personal messages, socialization and installation of bans on violations of local regulations as media information, in addition to news at the Denpasar City Government website and the distribution of Regional Regulation Number 2 of 2015 as a means of socialization using print and electronic media which is a means of delivering information. Apart from budget constraints and the unavailability of land for relocation for street vendors, Satpol PP as the implementor works in accordance with the duties and authority according to the wishes of the policy makers above.

The resources of equipment or facilities that support the performance of law enforcement have been sufficiently met, from the results of observation, office facilities and office space of Satpol PP have been fulfilled, and each field patrol, members have used available operational vehicles. Operational facilities and vehicles which then support the performance of the Denpasar City Satpol PP in carrying out their duties as law enforcement.

While the inhibiting factors that are constraints are related to inadequate budgets for the operation of PKL structuring and data collection, unavailability of locations intended for relocation, lack of public understanding of the existence of Perda, and humane elements of policing activities and confiscation of merchandise by Satpol PP.

The contents of the street vendor structuring policy in Denpasar City have been clearly stated in the Denpasar City Regulation. However, in its implementation, the realization of policy content regarding the arrangement of street vendors is still faced with several obstacles that are not as expected. Constraints faced were related to inadequate budgeting for the operation of PKL structuring and data collection, the unavailability of locations intended for relocation, lack of understanding of the community regarding the existence of the Perda, and the humane elements of policing activities and confiscation of merchandise by Satpol PP.

Implementor is Denpasar City Satpol PP and PKL is the target group of Regional Regulation No. 2 of 2015. In its implementation, the Implementor is limited to conducting local regulation socialization, coaching for PKL, and routine patrols, not arranging the existence of street vendors and then handing over management to traditional villages and banjar and PD Pasar for relocation to create beauty, cleanliness and comfort of Denpasar City. PKL who are not coordinated by the village or banjar adat or PD Pasar, do not have the knowledge of Perda Number 2 of 2015 and continue to sell even though they are often netted due to economic reasons.

Other constraints that affect are environmental factors. The number of street vendors that continues to grow and the area that cannot develop causes the density of Denpasar City to increase. The apparatus cannot prohibit migrants from seeking work because it is the attraction of the provincial capital. In addition, the lack of awareness of PKL, especially unorganized street vendors and the community to take care of the cleanliness of the environment and comply with applicable regulations, as well as inadequate parking areas also become environmental constraints for street vendor arrangement in Denpasar City.

\section{Conclusion}

Implementation of Local Law No. 2 of the Year 2015 which regulates street vendor arrangement in Denpasar City has not been running optimally. This can be seen from the results 
of observation that there are still many street vendors who are netted and the number of street vendors in Denpasar City continues to increase.

There are several supporting factors in the implementation of the regulation of street vendors in Denpasar City, namely: the suitability of the amount between the quantity and quality of human resources in this study. While the inhibiting factors that are constraints are related to inadequate budgets for the operation of PKL structuring and data collection, unavailability of locations intended for relocation, lack of public understanding of the existence of Perda, and humane elements of policing activities and confiscation of merchandise by Satpol PP.

Based on the description above, several recommendations can be submitted which might be used for improvement in handling street vendor arrangement in Denpasar City. First, in the context of upholding the Regional Regulation, it is necessary to consider not only sanctions, but also solutions to organize street vendors in accordance with the intended location as stated in the Perda Perda No. 2 of 2015. The availability of adequate budget and location, is one solution for managing the existence of street vendors in Denpasar City. City Government and Satpol PP can establish cooperation with villages and banjar adat as an alternative choice of street vendors arrangement, so that the existence of street vendors can make a real contribution in supporting the economy and remain supported by the clean, healthy, beautiful city environment and improve the economy of the community in accordance with the City icon Denpasar which has a cultural perspective in accordance with the philosophy of Tri Hita Karana.

The government, especially the City Government, Satpol PP, as well as the villages and customary groups must be more consistent in carrying out the Regional Regulations that have been made and can establish cooperation in managing the existence of street vendors in their regions, and the government is expected to review and equalize tariffs on quoting village fees and adat banjar on PKL in Denpasar City if it feels contrary to the Regional Regulation that has been determined by the City Government, so as to create equality and economic prosperity in the City of Denpasar.

\section{References}

Islamy, Irfan. 2009. Principles of State Policy Formulation. Jakarta: Bumi Aksara.

Kurniadi, T. dan Tangkilisan, H.N. 2002. Public Order and Street Vendors in DKI Jakarta. Yogyakarta.

Kartasasmita, G. 1996. Development for the People: Integrating. Growth and Equity. Jakarta: CIDES.

Madjid, Abdul. 2013. Learning Strategies. Bandung: PT Remaja Rosdakarya.

Sastrawan, I W. 2015. Analysis of Factors Affecting the Selection of Business Locations of Street Vendors in Penimbangan Beach, Buleleng Subdistrict, Buleleng Regency. Jurnal Pendidikan Ekonomi Undiksha, Vol. 5 No. 1 Tahun 2015.

Wahad, S.A. 2001. Policy Analysis from Formulation to State Policy Implementation. Second Edition. Jakarta: Bumi Aksara. 